H. Pötzsch and V. Šisler: 'Playing Cultural Memory', Games \& Culture, 2016 (online first)

\title{
Playing Cultural Memory: Framing History in Call of Duty: Black Ops and
}

\author{
Czechoslovakia 38-89: Assassination
}

Holger Pötzsch ${ }^{1}$, UiT Tromsø

Vít Šisler, Charles University in Prague

\begin{abstract}
$\underline{\text { Abstract }}$
The present article brings game studies into dialogue with cultural memory studies and argues for the significance of computer games for historical discourse and memory politics. Drawing upon the works of Robert Rosenstone and Astrid Erll, we develop concepts and theories from film studies and adapt them to respond to the media specificity of computer games. Through a critical reading of the first chapter of the history-based first-person shooter Call of Duty: Black Ops (Activision, 2010), the article demonstrates how the game's formal properties frame in-game experiences and performances, and this way predispose the emergence of certain memory-making potentials in and through constrained practices of play. Subsequently, an analysis of the serious game Czechoslovakia 38-89: Assassination (Charles University in Prague/Czech Academy of Sciences, 2015) shows the potentials of game design to facilitate meta-historical reflections and critical inquiries.
\end{abstract}

\section{Keywords:}

History, memory studies, game studies, simulation, Call of Duty: Black Ops, Czechoslovakia 38-89: Assassination, memory politics

\footnotetext{
${ }^{1}$ Corresponding author: holger.potzsch@uit.no
} 
H. Pötzsch and V. Šisler: 'Playing Cultural Memory', Games \& Culture, 2016 (online first)

\section{Introduction}

The present article sketches out a methodological template for an assessment of potential memory-effects connected to history-based, simulated game worlds. Drawing upon Rosenstone's (2006) work on the varying relations between film and history, and developing further the distinction between intra-medial, inter-medial, and pluri-medial levels of analysis of cultural expressions suggested by Erll (2008), we outline how the first-person shooter Call of Duty: Black Ops (Activision, 2010) creates a particular memory-making potential at the level of narrative and game mechanics. These findings are then contrasted with reference to Czechoslovakia 38-89: Assassination (Charles University in Prague/Czech Academy of Sciences, 2015), a serious game for education designed to invite meta-historical reflections. In both cases, we do not argue for a determinate impact of games on players or historicopolitical discourses, but describe the textual features through which certain responses and particular subject positions are systematically invited and certain understandings encouraged, before these are actively negotiated in situated practices of reception.

\section{Films, Games, History, and Memory: Re-Working Concepts and Frames}

After an initial focus on monuments and artefacts as sources of static knowledge about the past (Nora, 1984; Assmann, 1992), the field of cultural memory studies has shifted emphasis toward analysis of how contingent memory-potentials are mediated and negotiated in and through a variety of cultural expressions (Landsberg, 2005; Erll, 2011; Erll \& Rigney, 2009). In connection to this turn toward a fluid understanding of cultural memory inspired by for instance White's (1980) approach to narrative and discourse as constitutive elements of history, questions of how particular representations - fictitious and otherwise - invite certain understandings of the past and discourage others has moved centre stage. However, in spite of recent focus on the interrelation between computer games and history (Schut, 2007; Uricchio, 
H. Pötzsch and V. Šisler: 'Playing Cultural Memory', Games \& Culture, 2016 (online first)

2011; McCall 2012; Chapman, 2013), so far no studies have investigated the interrelation between games and cultural memory. Taking approaches to the role of film in processes of collective commemoration as a point of departure, the present article aims at bringing into dialogue the fields of game studies and cultural memory research.

Asserting an inherent salience of popular culture for historical thinking and practice, Rosenstone (2001, 2006) argues for the necessity of treating film as an autonomous medium of history, rather than measuring it in relation to criteria implicitly designed for assessments of written narratives. In his reevaluation of film, he distinguishes between three different modes through which the moving image can assert relevance for historical discourse and memory politics: history as drama, history as document, and history as experiment (Rosenstone, 2001, p.52). Each of these types, he explains, is connected to particular genres that affect how collectives approach and negotiate past events.

For Rosenstone, historiography is not a linear description of allegedly unequivocal past events, but a temporary freeze-frame highlighting one among many possible versions of an ultimately unattainable past. Contingent and negotiated objectification, rather than objectivity, as such emerges as the most salient feature of historical representations that, even in their most denotative form, depend on certain techniques of narrativization and emplotment that dramatize, focalize, create causal links between, and selectively frame past events (White 1980). Cultural memory studies assert that not only written texts emanating from a historical profession, but all kinds of cultural expressions play a role in this formation and negotiation of a "metaphorical dimension" (Rosenstone, 2006, p.36) of history.

When relating Rosenstone's framework to the field of game studies, it becomes apparent that also computer games with historical themes function in the three categories of history as drama, as documentary, and as experiment. To provide a few examples, the game Call of Duty: Black Ops involves players in a dramatization of cold war history that filters key 
H. Pötzsch and V. Šisler: 'Playing Cultural Memory', Games \& Culture, 2016 (online first) events through a fictitious player character - special-forces soldier Alex Mason. The game invents several historical events and creatively reimagines others (such as the murder of J. F. Kennedy). On the other hand, the serious game Czechoslovakia 38-89: Assassination enables players to actively engage in documented historical events and perceive these from the often contradictory vantage points of differently situated eyewitnesses. Lastly, Spec Ops: The Line (Yager Development, 2012) uses the entirely fictitious setting of the town of Dubai swallowed by a giant sandstorm to expose players to the intricate logics and devastating psychological and communal long-term consequences of warfare. In doing so, the game elegantly comments upon and challenges key conventions of the military third-personshooter. We argue that while Call of Duty: Black Ops acquires the function of history as drama, Czechoslovakia 38-89: Assassination approaches the type of history as document, while Spec Ops: The Line's most salient feature is history as experiment.

When dealing with history in computer games, issues of representing past events have to be supplemented with attention to the ways through which players are actively engaged in the (re)enactment and (re)shaping of these incidents (McCall, 2012; Peterson, Miller, and Fedorko, 2013; Chapman, 2012, 2013). As such, to be able to sufficiently account for the interrelation between computer games, historical discourse, and cultural memory, a fourth category - history as simulation - has to be included into Rosenstone's typology. This way, Rosenstone's framework can be adapted to enable a better understanding of the possible memory-making effects of history-based game narratives and experiences of play.

\section{Simulation and the Interpretation of History}

In games, history as simulation engages players not only through its narrative and representational frames, but also at a procedural and performative level (Bogost, 2007; Galloway, 2006; McCall, 2012; Chapman, 2012, 2013). This level directly involves players as 
H. Pötzsch and V. Šisler: 'Playing Cultural Memory', Games \& Culture, 2016 (online first)

actors in historical events and renders these available as interactive experiences. As a consequence of this, critiques that exclusively focus on games' historical content are often misguided.

Returning to the examples presented above, it can be argued that even though Call of Duty: Black Ops, Czechoslovakia 38-89: Assassination, and Spec Ops: The Line, function in each their respective category of history as drama, documentary, and experiment, they all enable the emergence of various contingent versions of real or imagined wars in and through simulated events. Players acting in these settings are released into authentic "problem spaces" (McCall, 2012) that enable more or less significant choices in the context of (necessarily simplified) past settings. This performative dimension of history as simulation entails consequences for an understanding of the relation between cultural memory and games.

In contrast to films or novels, in computer games every act of play will give rise to a different representation. While for instance a historical film constitutes one representation that is then interpreted differently by various audiences in particular contexts of reception (figure 1), acts of gameplay bring forth series of conditioned representations that are then read and negotiated by audiences. As Uricchio (2011, p.333) puts it, "simulation is capable of generating countless encounters that may subsequently be fixed as representations".

Figure 1: Interpretation and discourse in historical representations

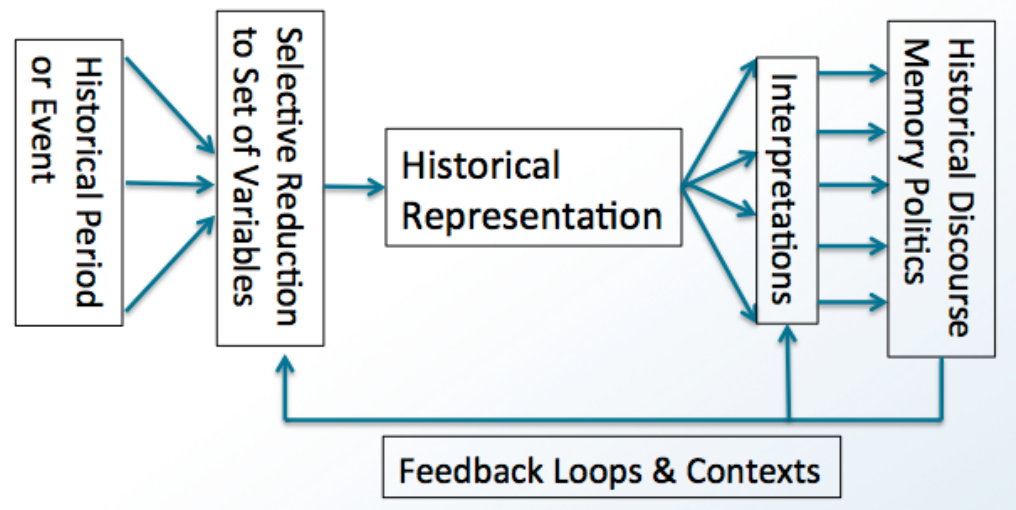


H. Pötzsch and V. Šisler: 'Playing Cultural Memory', Games \& Culture, 2016 (online first)

Chapman (2012) elaborates on these procedural potentials of the game form for historiography. He argues that in historically inspired game titles, it is precisely the multiplicity of possible narratives that enables critical reflection about the nature of historical discourse and practices of framing and selection. History as simulation enables creative practices of experimentation that allow for playful encounters with a variety of possible pasts. As such, notes Chapman (2012), the game form invites meta-historical considerations and critical reflection to a higher degree then for instance film or written works. In this lies the specific significance of games for the formation and negotiation of cultural forms of memory.

The content of the historical representations emerging through practices of play is not entirely dependent upon the decisions of individual players. Rather, game mechanics, procedures, and narrative devices predispose the paradigm of possible representations that reappropriative practices of play can give rise to. As such, games' potential effects on historical discourse and memory politics are contingent upon both the subjective selection of certain variables by designers and developers (aesthetic form), as well as upon the active engagement of these textual frames by players (re-appropriative practices of play). Together, these give rise to series of more or less conditioned historical representations (figure 2).

Figure 2: Representation, interpretation, and discourse in historical games and simulations

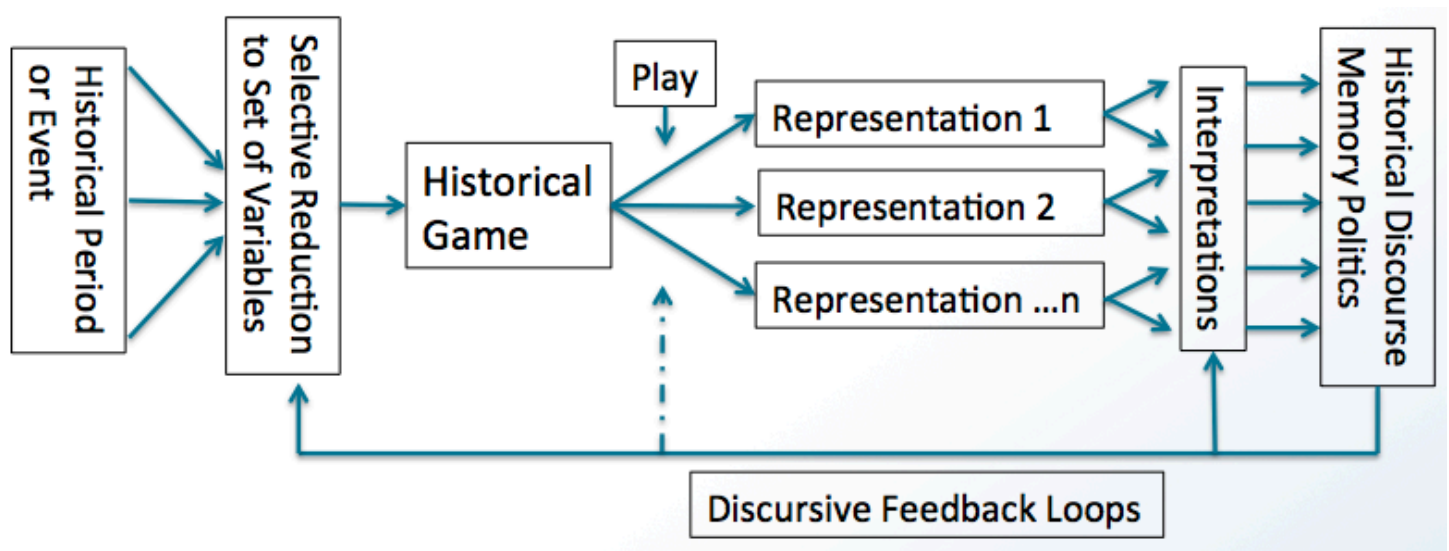

Depending upon the degree of openness of the narrative and procedural frames of the game at hand, the emerging historical representations can be quite similar and differences 
H. Pötzsch and V. Šisler: 'Playing Cultural Memory', Games \& Culture, 2016 (online first)

mainly the result of tactical decisions on various battlefields, or they can lead to fundamentally different narrative outcomes of simulated campaigns or wars. Some games invite higher degrees of exploration and potential rescriptings of history than others. The subsequent analysis will show that Call of Duty: Black Ops and Czechoslovakia 38-89: Assassination represent respective counterpoints on this scale.

\section{Playing the past: Assessing Memory-Making Potentials in Films and Games}

Many scholars today agree that, regardless whether presented through literature, films, or games, "history is always a reductive exercise of capturing the evidence of the past and transcoding it into an assimilable narrative" (Chapman, 2013, p.323; emphasis in original). As such, the interesting question is not so much whether, or not, films or games are suitable media for the dissemination of historical knowledge, but what specific historical variables are considered salient by the director or designers, how these variables are presented and framed by aesthetic form, and how players can negotiate these in constrained practices of play. Consequently, analysis of how specific games or genres selectively reduce complexity to create simulated historical environments that frame player experiences and performances becomes a crucial focus of studies interrogating the potential role of games in the cultural negotiations of shared pasts.

Several recent studies have directed attention to the ways through which games filter and frame experiences of the past at the level of both procedure and narrative. Schut (2007), for instance, identifies a procedurally generated bias in historical simulation games that according to him tend to 1 ) produce a stereotypically masculine image of history as dependent upon top-down decisions by powerful white men, 2) present history as essentially "a clear chain of cause and effect" (p.223), and 3) reduce complex socio-political and economic developments to predominantly spatially oriented forms of violent interaction. Salvati and 
H. Pötzsch and V. Šisler: 'Playing Cultural Memory', Games \& Culture, 2016 (online first)

Bullinger (2013) on the other hand note a "selective authenticity" (p.154) through which war games scaffold player engagements and tie them to established historical master narratives, while Pötzsch (2015) identifies four filters through which the mechanics and narratives of first- and third-person shooters tacitly exclude salient, yet unpleasant, features of warfare such as suffering civilians, sexually motivated forms of violence, racism, and others.

Assessments of the potential impacts of computer games on processes of collective commemoration and memory politics necessitate a methodological framework that either focuses on actual practices of play or that analyzes the formal properties through which such practices are limited and predisposed. While the first venue employs empirical methods such as participant observation or interviews with players and takes its cues from disciplines such as psychology or sociology, the second takes an aesthetic course and describes the narrative and procedural means through which certain potentials for meaning and practice are brought forth. The present article follows the second strain and connects game mechanics and narratives of war-themed titles to certain potentials for historical meaning and practice. To do this, we will introduce the methodological framework proposed by Erll $(2008,2011)$ for analysis of historical films and adapt it to the media specific properties of computer games.

Taking film as conveyor of historical knowledge as point of departure, Erll (2008) proposes three interrelated levels of analysis to assess the memory-making potentials of movies and other cultural expressions. She distinguishes between an intra-medial, an intermedial, and a pluri-medial analytical focus. An intra-medial approach looks at the formal means and devices through which film (and other media) construct historically inspired diegetic universes and invite particular forms of engagement with the past. Also an intermedial analysis looks at formal textual elements. Here, however, attention is directed to the ways through which a particular representation refers to, comments upon, or re-contextualizes preceding representations dealing with the same historical period or event. 
H. Pötzsch and V. Šisler: 'Playing Cultural Memory', Games \& Culture, 2016 (online first)

According to Erll (2008), both the intra- and inter-medial levels of analysis merely point to a certain potential for memory-making, but cannot account for the ways through which a certain historical representation is read by situated audiences. Only the third level of analysis - the pluri-medial component - looks into the processes through which the meaning potentials are disseminated to, and activated, negotiated, and/or subverted by, concrete audiences in varying contexts of reception. Both empirical audience research and analysis of distribution patterns, reviews, or educational packages provide perspectives on this plurimedial level. Given the peculiarities of computer games as interactive audio-visual media, however, the intra-medial level of analysis will have to be further distinguished into two separate areas of inquiry, namely game mechanics and narrative.

In the following we will conduct an analysis of the historically inspired FPS-game Call of Duty: Black Ops along the lines suggested by Erll (2008). Then, we move on to an analysis of the educational title Czechoslovakia 38-89: Assassination that approaches historical meaning and practice in a different, more experimental way. We argue that while Cal of Duty: Black Ops functions in the category of history as drama, Czechoslovakia 38-89: Assassination most salient characteristic is history as document and experiment.

\section{Framing Historical Problem Spaces: Playing the Past in Call of Duty: Black Ops}

Call of Duty: Black Ops (Activision, 2010) is the seventh in a series of currently 11 firstperson shooter games that together form the Call of Duty-franchise (2004-). Initially, the series placed players on various battlefields of the Second World War and reiterated the morally rather unambiguous narrative of a greatest generation composed of mainly US American ground troops fighting the good war against unequivocally evil Nazi soldiers. After Call of Duty: Modern Warfare (2008) and Call of Duty: Modern Warfare 2 (2009), the game under scrutiny in this section is the third in the series that leaves behind a World War II 
H. Pötzsch and V. Šisler: 'Playing Cultural Memory', Games \& Culture, 2016 (online first)

setting and directs attention to the more hidden, paranoid, and morally ambiguous forms of military intervention characteristic of the Cold War and its rivalry between Eastern and Western secret services and clandestinely operating military forces. Whereas the World War II titles of the franchise let the player take control of simple troopers involuntarily cast into an industrialized slaughter, Call of Duty: Black Ops features the professional special-forces soldier Alex Mason as main player character and follows him across various prominent theatres of cold war confrontation.

Call of Duty: Black Ops is a straightforward first-person shooter that can be played either in a de-contextualized multi-player mode that pits groups of networked players up against one another, or in a story-driven campaign mode where action intensive map-based fighting sequences are connected through cinematic cut scenes that drive forth a historically inspired narrative. The present contribution will take a look at the first chapter of the campaign mode and analyze how the game frames and reframes cold war history with reference to the attempted US-led invasion of Cuba in 1961.

\section{Inter-Medial Analysis: Authenticity and History}

According to Erll (2008) the inter-medial level of analysis directs attention to the intertextual connections between a given historical representation, available documents, and a wider historical discourse. As such, the inter-medial level is usually the place where questions of authenticity are negotiated and where memory-making potentials are generated with reference to implied connections to available evidence. In Call of Duty: Black Ops, the opening sequence plays an important role in this respect.

The game's opening sequence can be distinguished into three parts: 1) a short title sequence that discursively situates the game and acknowledges key legal titles, 2) an intermediary cut scene posing a central puzzle to be solved throughout the narrative, and 3) an 
H. Pötzsch and V. Šisler: 'Playing Cultural Memory', Games \& Culture, 2016 (online first)

opening scene that gradually assigns control over the main protagonist to players and effectuates their transition into the diegetic problem space of the game. In all three parts, inter-medial references connect game world and narrative to the historical period of the cold war and this way generate certain expectations to be able to explore authentic historical settings.

The title sequence of Call of Duty: Black Ops consists of a series of unsteady and partly overexposed images, text files, and film clips that rapidly flash over the screen. The shaky and quivering documents contain three sets of information. Firstly, they acknowledge legal titles of production company and developers. Secondly, and important for the present inquiry, iconic historical images and film clips showing familiar cold war politicians or wellknown scenes and settings, function as inter-medial references that connect the evolving game world to key locations and incidents of cold war confrontations, while, thirdly, the brief exposure of heavily redacted official documents situates the game within a discourse of clandestine military operations and government secrecy.

Taken together, these devices invite players to perceive the depicted persons, game maps, and events as realistic and based factual historical incidents. This charges the initial transition of the player into the diegetic universe with expectations of being able to act in authentic environments and to vicariously experience simulated cold war history first-hand. However, the redacted nature of the documents inserts the additional expectation of taking part in operations previously unknown to the general public inviting for partly counterfactual acts of play.

The intermediary cut scene following the title sequence consists of a close-up on 1960s style radio broadcasting equipment and the face of young woman relentlessly speaking a series of numbers into a microphone. This scene prefigures the major puzzle of the game that is immediately reiterated in the following opening scene that is situated in what appears 
H. Pötzsch and V. Šisler: 'Playing Cultural Memory', Games \& Culture, 2016 (online first)

to be a high-tech interrogation room and introduces the main character, Alex Mason, tied to a chair and exposed to series of apparently meaningless questions interrupted by electroshocks. During the sequence, players learn that they control a character who lost his memory, who is plagued by series of numbers he is unable to get out of his head, and that he is interrogated about his past deployments as a special forces soldier by an unknown and estranged voice.

The main part of the subsequent game narrative is played out as a series of memories of the main protagonist that take players back to various undercover operations Mason apparently has taken part in from the attempted Bay of Pigs invasion in Cuba in 1961, via various locations in the former Soviet Union, Vietnam or Laos, and up to a final confrontation at sea close to the coast of Cuba in 1968. The various theatres of conflict are interconnected by loading screens that in a style reminiscent of the title sequence historically situate each game map, as well as repeated scenes in the interrogation room that gradually solve the game's puzzle. The story reveals the struggle of US secret service agents against a deadly threat posed by Soviet agents who have embedded a huge number of sleeper cells in the US and threaten to make them detonate deadly toxic agents across the entire country.

As a creative twist to established game narratives, main player character Alex Mason himself emerges as a brainwashed Soviet sleeper agent. Even though he finally breaks the neuro-programming, kills his main adversary, and thus saves the day in a rather generic course of events, the game's end sequence more than hints at a direct involvement of Mason in the murder of John F. Kennedy, thus connecting the narrative to a major source of conspiracy theories from the cold war. Also the use of neuro-programming techniques to remote control humans emerges as a familiar trope that draws upon a body of inter-medial references first and foremost established in cold war movies such as The Manchurian Candidate (John Frankenheimer, 1962) or Telefon (Don Siegel, 1977). 
H. Pötzsch and V. Šisler: 'Playing Cultural Memory', Games \& Culture, 2016 (online first)

In sum, the inter-medial layer of Call of Duty: Black Ops clearly situates the game's narrative in a recognizable historical period, but fails to contextualize in-game events and characters in a detailed manner. As such, the brief flashes of secret documents and iconic imageries fail to do justice to the complex and contradictory socio-economic backgrounds of the simulated cold war incidents. One exception might be the brief visual reference to "Operation 40" that might induce players to find out more about this particular secret CIAprogramme designed to topple left-leaning governments in Central and South America (figure 3). ${ }^{\mathrm{i}}$

Figure 3: A reminder of unpleasant aspects of US-Cuban relations: Reference to Operation 40 in the opening sequence of Call of Duty: Black Ops

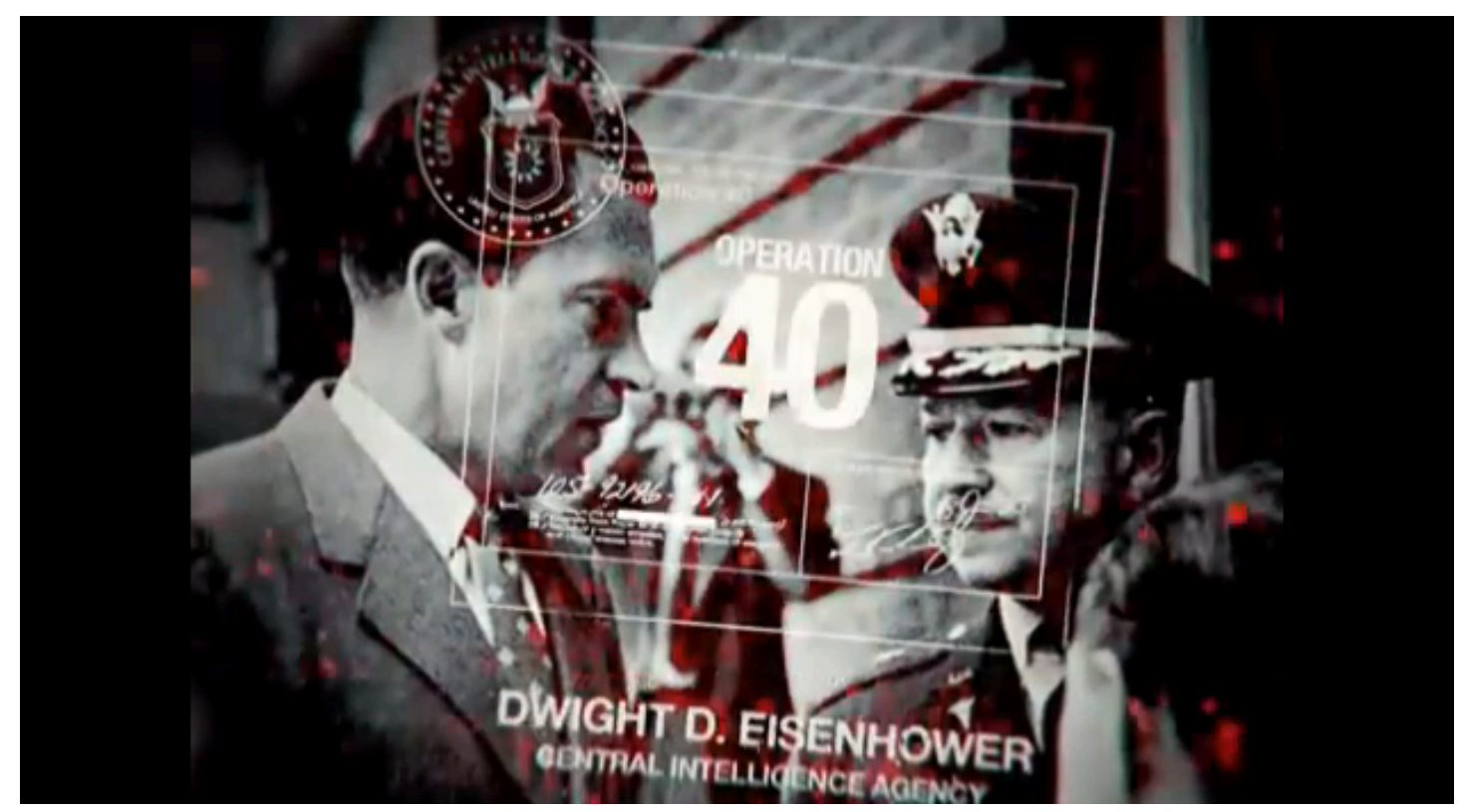

We will now move on to an intra-medial level of analysis to assess how the intermedial frames highlighted above are rearticulated through the narrative and mechanics of the game. Particular emphasis will be directed to the game's first chapter set on Cuba in 1961.

\section{Intra-Medial Analysis: Narrative Devices and Game Mechanics}

The first chapter of Call of Duty: Black Ops is set on Cuba during the Bay of Pigs invasion in 1961. The player is sent on a special mission to the island with the objective of killing then 
H. Pötzsch and V. Šisler: 'Playing Cultural Memory', Games \& Culture, 2016 (online first)

president of Cuba Fidel Castro. During the operation player character Mason kills what later emerges as Castro's double and is taken prisoner by his main adversary thus setting the scene for game chapter 2 playing out in a prison labor camp in Vorkuta, Soviet Union.

The first chapter commences with a cinematic cut scene in a Cuban bar where Mason and his two companions meet with a local contact. Besides reiterating mission objectives, the opening scenes deploy several cues to provide implicit justification to the US-led intervention and to the ensuing violence conducted by the player on behalf of Mason and his team. Firstly, local contact man Carlos is framed as representative for a segment of Cuban society that supports US military action, including the assassination of the Cuban president and a fullscale military assault on the country. In addition, the Cuban police officers entering the scene are presented as brutish bullies who harass a woman, and who advance aggressively toward Mason and his companions. These narrative frames enable a form of moral disengagement (Hartmann and Vorderer 2010) that makes the subsequent massive violence executed by players appear legitimate and without an alternative.

During the subsequent fighting sequence, the game mechanics of Call of Duty: Black Ops reduce player freedom to mere tactical choices such as which weapon to use, or where and how to hide from enemy fire. The default mode of interaction with opposing non-player characters (NPCs) is violence and no other option is left to the player but to shoot and kill while advancing through the pre-scripted map. As such, Call of Duty: Black Ops precludes a creative exploration of the game world. In addition, in framing all enemy NPCs as immediate threats and disallowing any form of interaction other than implicitly justified massive violence, a monolithic understanding of the historical conflict is invited that disregards sociopolitical complexities and reduces manifold Cuban subjectivities to a simple binary distinction between immediate threat and occasional innocent bystander. This interactive 
H. Pötzsch and V. Šisler: 'Playing Cultural Memory', Games \& Culture, 2016 (online first)

framing of historical discourse and practice at the level of game form becomes particularly palpable in the encounter of the player with former Cuban president Fidel Castro.

After having defeated rows of enemies with increasing strengths and capabilities, the player finally reaches Castro's inner chamber. When approaching the door, a series of quicktime events is triggered that force player actions into a narrowly scripted course of events. With the words "ready to make history?", Mason pushes open the massive door to Castro's bedroom, where the Cuban president emerges in iconic military suit hiding behind a woman who wears a sexy night gown (figure 4). As Mason pulls the trigger of his gun, a cut scene in slow motion follows the emerging bullet until it hits Castro in the head. Once the main opponent is dead, the woman takes up a weapon and tries to attack, while control is handed back to the player who can choose to either shoot her or let companion Woods kill her. After this action scene, a scripted verbal exchange between the two American soldiers anchors the sequence both morally and politically, and metaphorically extends the specific incident as representative for the historical conflict as a whole. Again, player involvement is limited to a passive reception of ready-made game content.

Woods states that the woman is a "crazy bitch" who was used by Castro as "human shield and she still protects him". Mason responds on behalf of the player that "Castro's supporters are fanatical in their devotion to him..." Here, the Cuban president is presented as a coward, hiding behind civilians, yet spawning a form of insane fellowship, while possible in-game performances by players are tied to a repetitive reiteration of these narrow narrative frames. As such, rather than enabling a playful exploration of underlying ambiguities, or a counterfactual testing of different possibilities for historical agency, players are lulled into a tiring generic scenario that caricatures any form of opposition to US interests as the result of incomprehensible evil. 


\section{Figure 4: Killing Castro in Call of Duty: Black Ops}

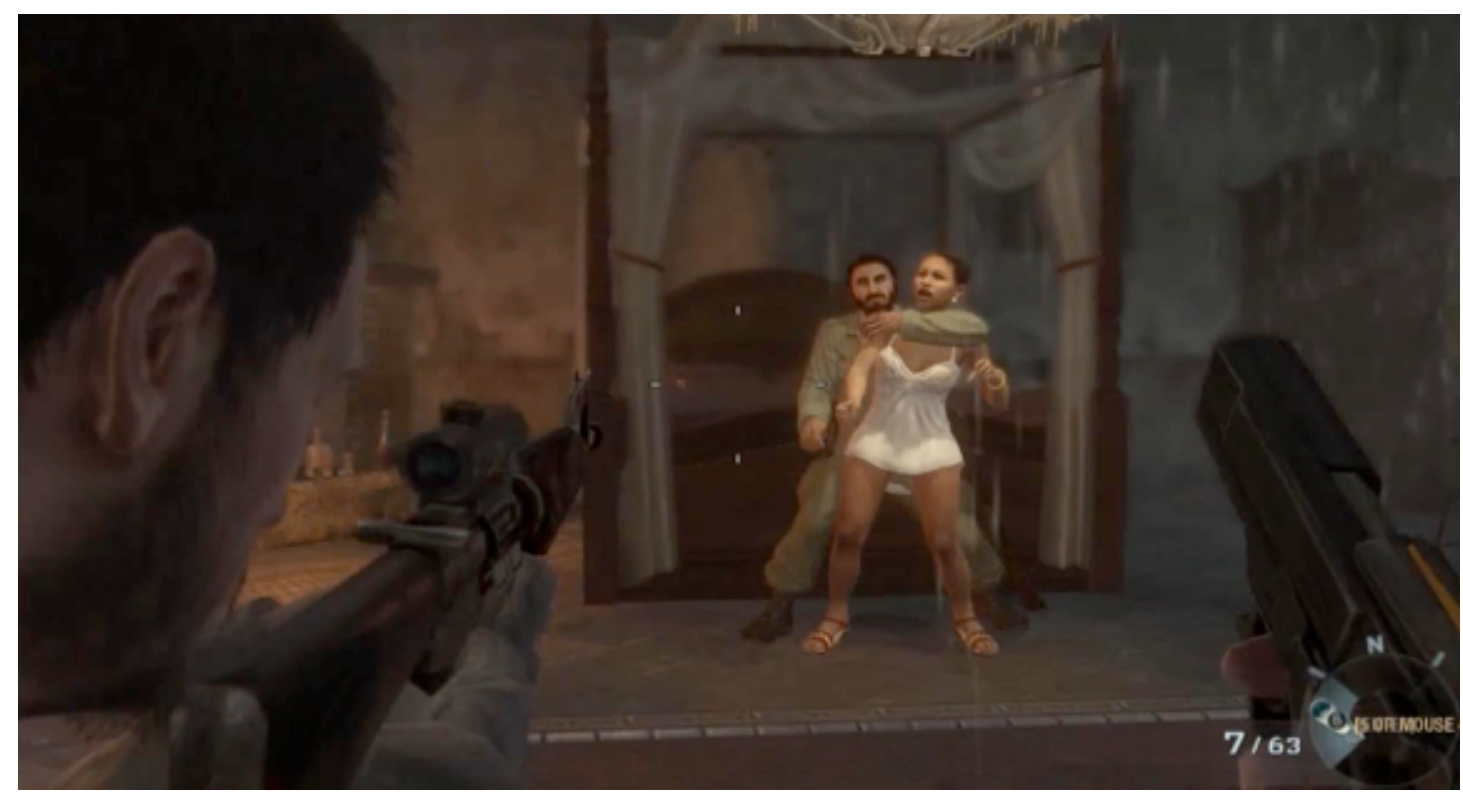

In sum, the game's intra-medial level systematically diverts attention away from the socio-political and economic background of the Cuban revolution and, through an interplay of narrative and game mechanics, reduces the complexities of Cuban society and politics to a simple binary opposition. The game conjures up a simulated problem space that narrowly frames possible in-game choices and ties player performances to a narrowly scripted setting. The ability of players to actively interfere with, and potentially challenge or subvert, the course of events is limited by game mechanics that disable all but directly battle-related and merely tactical choices. Players are invited to perceive historical processes as driven by unambiguous dichotomies such as sanity - madness, good - evil, heroism - cowardice rather than the result of balanced assessments and carefully deliberated decisions by rational actors.

However, through the explicit connections drawn at an inter-medial level between the game world and factual cold war incidents, the generic narratives emerging from conditioned practices of play are charged with memory-making potentials that expand the Manichean normative frames into the realm of historical representation of real-world actors and events. This does not mean that players will necessarily represent their experiences of play in such 
H. Pötzsch and V. Šisler: 'Playing Cultural Memory', Games \& Culture, 2016 (online first)

historical terms, but merely points to certain memory-making potentials invited at the level of game form.

\section{Pluri-medial analysis: Memory/Politics}

A pluri-medial analysis looks into contextual factors that might facilitate or undermine the realization of the various memory-making potentials established at an inter- and intra-medial level. Here, questions of reception, dissemination, and educational or other forms of appropriation become salient.

The title Call of Duty: Black Ops was a major commercial success. The release of the game on November 9, 2010 was a carefully devised marketing event. Oversized posters with the title and iconic image of a soldier, face in the shadows, holding two hand-guns across his chest were visible on billboards across major cities for the period of several weeks. Activision sold 5.6 million copies within 24 hours after release on US and UK markets alone (Associated Press, 2010a) and the game quickly turned into the best-selling video game ever (Bond, 2011). ${ }^{\text {ii }}$ This vast dissemination points to a wide availability and indicates good conditions for an actualization of the game's formal memory-making potentials.

In addition to its wide dissemination, the game triggered intensive engagements from the side of players. According to Bavelier (2012), Call of Duty: Black Ops had been played for an accumulated number of 600 million hours only one month after its release. ${ }^{\text {iii }}$ Generally, the game received very good reviews with an average ranking of above $80 \%{ }^{\text {iv }}$ These numbers reveal an intensive engagement with the game and point to a widespread availability of the conveyed historical narrative and frames. However, even though the narrative of the campaign mode triggered some protests from the Cuban government (Associated Press, 2010b), generally popular reviews focused more on game mechanics and playability than on critical assessments of historical accuracy. 
H. Pötzsch and V. Šisler: 'Playing Cultural Memory', Games \& Culture, 2016 (online first)

In scholarly discourse, on the other hand, the game has been acclaimed for its relevance for culturally framed re-imaginations of cold war history. Reisner (2013) for instance commends the ability of Call of Duty: Black Ops of "placing the player in the position of witness and immersing him/her in an authentic space" (p.250). According to him, the game connects to a "cultural archive of the Cold War" (p.250) by "digitally remodeling significant historical actors, actual locations and weapon types" (p.251). Arguing in a similar direction, Schulzke (2013) claims that Activision's game places players “in convincing environments that allow [them] to reenact history" (p.264) and concludes that Call of Duty: Black Ops "provides a broad overview of the many covert operations carried out by the American government during the 1960s" (p.264). Neither Reisner nor Schulzke, however, critically engage the game's formal properties - narrative devices and game mechanics - and how these invite biased understandings and one-sided reenactments of historical actors and events. The present contribution set out to alleviate this shortcoming by focusing on the ways through which Call of Duty: Black Ops rescripts the Bay of Pigs invasion in particular and US-Cuban relations in general along narrow normative lines effectuated both at the level of narrative and game mechanics.

As becomes apparent in the studies by for instance Pötzsch (2015), Ramsay (2015), or Salvati and Bullinger (2013), the reductive rhetoric of Call of Duty: Black Ops identified in the sections above is characteristic not only for this specific game, but points to a peculiar selectivity of the first- and third-person shooter genre in general. As such, the biased presentation of actors and interests in Activision's game, coupled with its disability to enable meaningful player choices beyond a mere tactical level, might not only matter in relation to the commemoration of the US-led attempted invasion of Cuba in 1961, but potentially acquires a wider significance. 
H. Pötzsch and V. Šisler: 'Playing Cultural Memory', Games \& Culture, 2016 (online first)

Pötzsch (2013) has argued that mainstream Hollywood film contributes to the cultural formation and maintenance of abstract "metascripts" (p.142) of war and the enemy that tacitly contribute to a general politics of othering independent of concrete historical actors or settings. For instance, the explicit representational layer of a war film such as Black Hawk Down (Ridley Scott, 2013) denotes a specific US intervention into the Somali civil war in the early 1990s. Implicitly, however, camera work, uses of slow motion, storyline, music, sound, and so on also function at a non-specific level where the concrete Somali opponent acquires the role of an abstracted, generic enemy-other. At this level, the formal means of the genre systematically invite the reproduction of a meta-narrative about a good and benevolent soldier-self involuntarily caught up in a violent struggle for survival against an incomprehensibly evil, aggressive adversary.

Pötzsch's (2013) main point is that Hollywood war and action cinema in general, regardless concrete settings and contexts, reproduces these abstracting frames that then function as key cultural references providing orientation in ambivalent and contradictory socio-political terrains. According to him, this aesthetics of othering draws an "epistemological barrier" (p.140) that precludes access to the potentially subversive subjectivity of the other. As such, the genre contributes to the cultural formation of frames of war (Butler, 2009, p.5) that tacitly predispose not only what we perceive as potential or actual threats, but also what we do not see and recognize, namely the opponent as "legitimate enemy" (Mouffe, 2009, p.102) and, ultimately, grievable life (Butler 2009, p.13). Based on this conceptual framework, it can be argued that also the peculiar aesthetics of Call of Duty: Black Ops, and the military shooter in general, reiterate this abstracted meta-narrative and play into similar discursive positions and social optics.

Having described the formal properties of Call of Duty: Black Ops, and having connected the game's mechanics and narrative to the emergence of certain reductive memory- 
H. Pötzsch and V. Šisler: 'Playing Cultural Memory', Games \& Culture, 2016 (online first)

making potentials in pluri-medial contexts, we will now turn our attention to a counterexample and show how Czechoslovakia 38-89: Assassination facilitates inclusive, multidimensional, and multi-perspectival understandings of historical conflicts and war.

\section{Playing the Past, Seriously: Czechoslovakia 38-89: Assassination}

Czechoslovakia 38-89: Assassination (Charles University in Prague/Czech Academy of Sciences, 2015) is the first in a series of currently 3 serious games that together form the Czechoslovakia 38-89-franchise (2015-). The series presents key events from Czechoslovakia's contemporary history and enables players to vicariously experience these from the vantage points of differently situated fictitious eyewitnesses. The first game in the series, Czechoslovakia 38-89: Assassination, is set during the Second World War and covers the period of brutal oppression following the assassination of Reinhard Heydrich, "Reichsprotektor" of the Nazi-occupied Czech Territories.

Czechoslovakia 38-89: Assassination is a single-player dialog-based adventure game that combines a historically inspired storyline with authentic documentary materials. Players assume control of a grandson or granddaughter of J. Jelinek, the fictional main protagonist of the evolving narrative, and engage in conversations with various eyewitnesses to reconstruct Jelinek's personal story and the reasons for his arrest after Heydrich's assassination.

\section{Inter-Medial Analysis: Authenticity and History}

Similar to Call of Duty: Black Ops, also in Czechoslovakia 38-89: Assassination the opening sequence employs a series of inter-medial references to predispose players' understandings of the relation between the diegetic universe of the game and real historical events. The opening can be divided into four parts: 1) a title sequence that acknowledges legal titles and contributions, 2) an opening sequence introducing the first eyewitness, 3) a short dialogue 
H. Pötzsch and V. Šisler: 'Playing Cultural Memory', Games \& Culture, 2016 (online first)

scene that assigns control over the main protagonist to players and effectuates their transition into the diegetic universe of the game, 4) and an interactive play sequence in form of an animated graphic novel that represents the first eyewitness's memories and that poses the central puzzle to be solved throughout the game (figure 5). In all four parts of the opening sequence, except the first, documentary images and recordings connect the game world to the historical period of the Nazi Protectorate of Bohemia and Moravia (1939-45) and frame game characters as authentic eyewitnesses. By these means expectations are raised of being able to explore realistic historical settings.

According to Chapman (2012), games and simulations have not only the inherent potential to convey certain historical facts, but in particular enable reflections about the nature of history and historiography in general, and to raise awareness for the ultimate contingency of any recollection of the past. In contrast to Call of Duty. Black Ops discussed above, Czechoslovakia 38-89: Assassination invites such meta-historical reflections in that it balances documentary movie clips and a quasi-authoritative frame narrative with an active exploration of idiosyncratic personal experiences and memories. The content of the various conversations players can conduct with in-game characters are based on historical research and authentic testimonies, yet the specific verbal exchanges are inventions (Šisler et al., 2014). As such, players are invited to reflect upon the situatedness of personal memories and to critically engage the constructedness of received perspectives on the past.

In sum, the inter-medial level of Czechoslovakia 38-89: Assassination clearly situates the evolving narrative in a recognizable historical period and enables attention to the contradictory, fragile, and fragmentary nature of personal memories. The game creates productive tensions between an allegedly authoritative historical frame and the fictionalized stories told by in-game characters. This inter-medial feature draws attention to processes of 
H. Pötzsch and V. Šisler: 'Playing Cultural Memory', Games \& Culture, 2016 (online first)

transcoding what Assmann (2008) terms communicative group memories into inherently institutionalized and heavily mediated cultural memory.

Figure 5: Interactive scenes reenacting recounted events in Czechoslovakia 38-89: Assassination

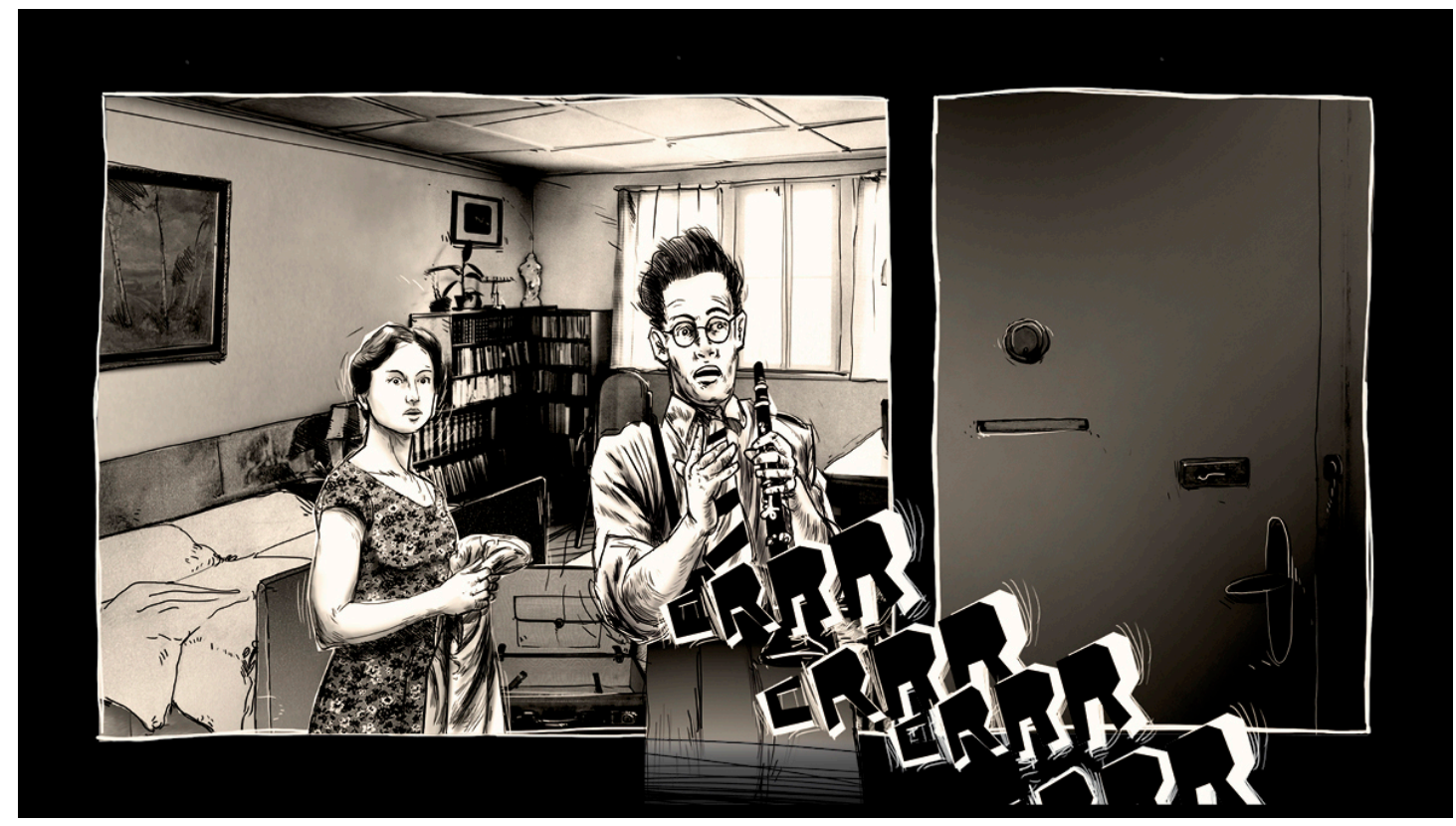

Intra-Medial Analysis: Narrative Devices and Game Mechanics

Gameplay in Czechoslovakia 38-89: Assassination mainly evolves around a series of conversations with different in-game characters that are interrupted by short interactive play sequences. The oral testimonies take players back to different times and places and enable the gradual resolution of the main puzzle concerning the reasons for their grandfather's arrest. During conversations, players can choose between different response alternatives from predetermined dialogue trees (figure 6). The selected answers predispose the further development of the story in that they enable or preclude access to further witnesses. Through these mechanics, players can influence the course of events and bring the evolving conversations somewhat into correspondence with their own interests, values, and ideas.

For example, during the interview with Josef Malek, a pro-German journalist during the Protectorate, players can choose to accuse him of collaboration with the German secret 
H. Pötzsch and V. Šisler: 'Playing Cultural Memory', Games \& Culture, 2016 (online first)

police Gestapo based on information acquired through conversations with other characters. Alternatively, this information can be ignored and players might proceed without conflict. Based on such choices, the course of future in-game events is influenced and various different layers of the historical narrative become accessible.

In Czechoslovakia 38-89: Assassination personal dramas play out on the historical canvas of the Nazi occupation. As such, idiosyncratic personal stories and family memories constantly intersect with allegedly authoritative accounts of the past as such. Players gain access to testimonies by Czech resistance fighters and civilians, Nazi collaborators, Jews, Roma, and the Sudeten-German minority. The game denies final closure and often leaves the player with the suspicion that a different choice of response at a certain point in the game might have lead to a different perspective on the events and this way to a different historical narration. It is precisely through such features that Czechoslovakia 38-89: Assassination enables a form of historical meta-knowledge identified by Chapman (2012) as the core affordance of history as simulation.

Furthermore, in-game conversations provide access to perspectives that usually remain underemphasized in Czech mainstream historical discourse. These include the memories of a Czech supporter of the Nazi-installed government, the testimonies of a Sudeten German whose family had been forcibly expulsed from Czechoslovakia after the Second World War, and the stories of a Roma girl who went through the atrocities of Porrajmos (the Roma genocide during the Nazi era) and who articulates the discrimination and abuse of the Roma population during the Nazi and Communist past, as well as in the current post-socialist period.

Czechoslovakia 38-89: Assassination does not allow players to change history - to take part in counterfactual historical developments. Rather, the gradual revelation of testimonies that highlight different and often contradictory features of an allegedly monolithic national past lies at the core of the game. As such, what is open to negotiation in and through 
H. Pötzsch and V. Šisler: 'Playing Cultural Memory', Games \& Culture, 2016 (online first)

play are discourses about the past, rather than the past itself. By means of its mechanics that frame players' in-game behavior and decisions, Czechoslovakia 38-89: Assassination makes a procedurally driven argument about the ultimate contingency of historical knowledge and about the fragile and multi-perspectival nature of individual memories and recollections.

As the developers state, their aim was to invite players to "critically evaluate the gained information, exert social skills and empathy, and analytically approach the social constructions of history" (Šisler et al., 2014). This reflective focus on contingency and discourse in Czechoslovakia 38-89: Assassination stands in stark contrast to the way the past is treated in the genre of the military shooter here exemplified through Call of Duty: Black Ops. While the former makes the constant negotiation of contingent stories and idiosyncratic recollections its explicit theme, the latter employs an apparently clear-cut and unambiguous historical setting as a mere background prop for a conventional shooter narrative.

Figure 6: Interactive conversation with a character in Czechoslovakia 38-89: Assassination

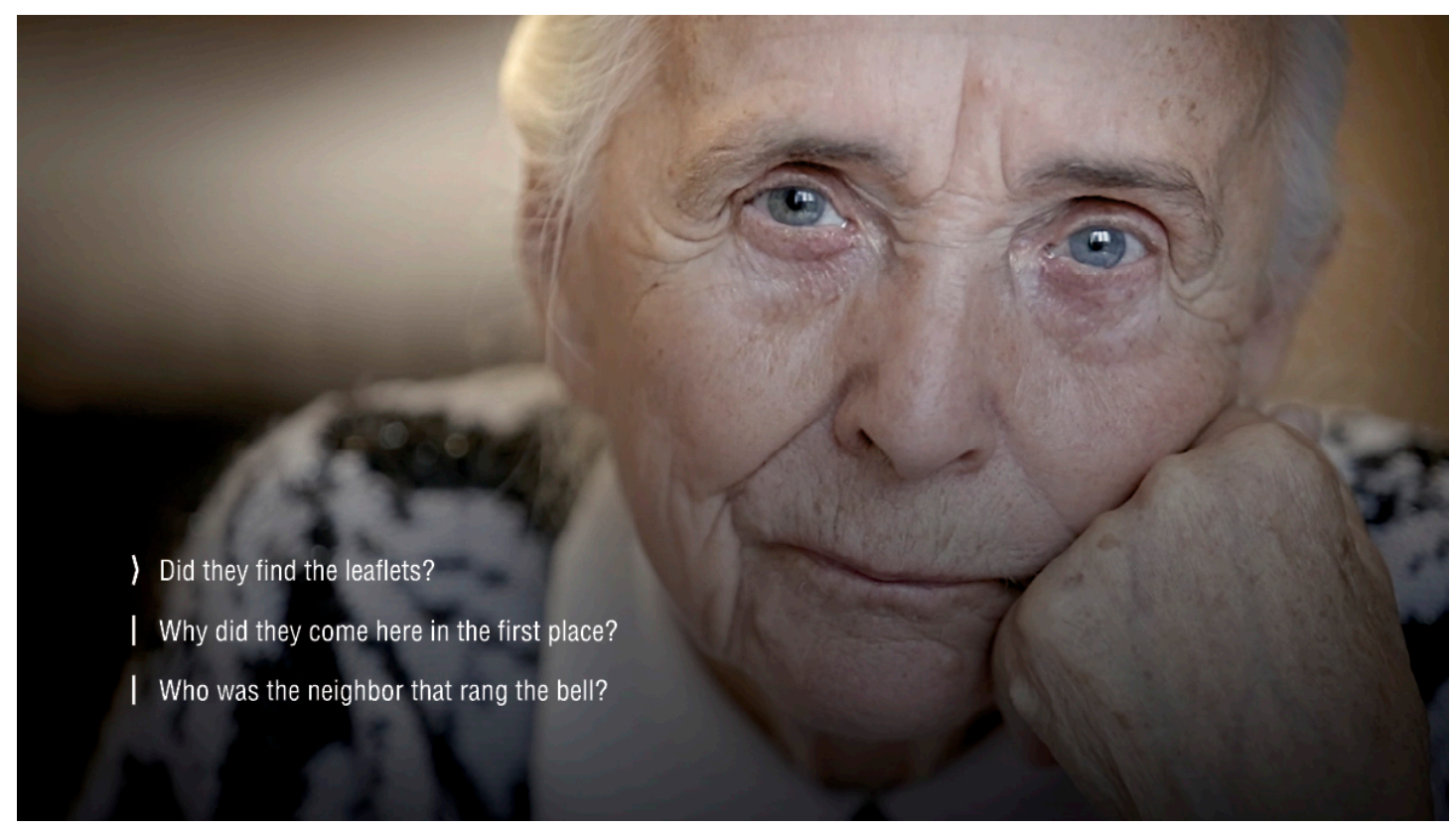

Czechoslovakia 38-89: Assassination's intra-medial level systematically emphasizes the varied and complex socio-political, cultural, and economic context of the given time period. Simultaneously, it presents history not as a set of unequvivocal events and definite 
H. Pötzsch and V. Šisler: 'Playing Cultural Memory', Games \& Culture, 2016 (online first)

conclusions, but rather as socially constructed - as inherently multifaceted, contested, and object for constant negotiation. This is achieved both at the level of narrative that presents a set of diverse personal testimonies and the level of game mechanics that afford an active exploration and critical questioning of received facts and frames. By these means, Czechoslovakia 38-89: Assassination emphasizes the situatedness of individual historical recollections and the ultimate contingency of any knowledge about the past.

\section{Pluri-medial analysis: Memory/Politics}

Czechoslovakia 38-89: Assassination has been released on June 4, 2015 in an educational and a commercial version. Both versions will be treated separately when sketching out some of the pluri-medial constellations within which the memory-making potentials of the game unfold.

A prototype of the educational version of the game has been tested in 13 Czech high school classes in 2013 (Šisler et al., 2014). A subsequent evaluation was conducted in form of quantitative questionnaires and qualitative self-reports among involved teachers and students. Results show that students perceived the game as a relevant and authentic source of historical knowledge. In particular, the combination of fictionalized personal testimonies with actual historical materials and documents was mentioned positively. According to the self-reports, the game created an immersive and motivating learning environment that enabled a transformation of history from abstract, yet authoritative, entity into idiosyncratic personal experiences and individual life-stories susceptible to interactive engagements by players.

Teachers reported that they perceive the game as an efficient learning tool that increased motivation to learn about Czech contemporary history, stimulated debates, and encouraged further inquiries by students. In particular they commended the multiple and often contradictory perspectives on the historical events that facilitated meta-historical learning. 
H. Pötzsch and V. Šisler: 'Playing Cultural Memory', Games \& Culture, 2016 (online first)

Self-reported assessment as a method for evaluation is not without drawbacks. This method is based on subjective feedback of informants that were condensed into final reports. No formal assessments of possible actual gains in historical knowledge have been conducted. In addition, the study sample cannot be seen as unbiased. Teachers who volunteered to adopt Czechoslovakia 38-89: Assassination as a teaching tool must be seen as potentially positively biased regarding the self-reported outcomes and impacts on teaching and learning. Nevertheless, we treat the results as a valuable indication for a certain degree of realization of the game's formal memory-making potentials in and through classroom use.

The launch of the commercial version of Czechoslovakia 38-89: Assassination has been widely publicized in the Czech press and on Czech television. Generally, reviews praised the game for its historical theme, graphical representation, and non-schematized depiction of history. Kouba (2015) for instance notes that the game "presents history from many perspectives", while Grygar (2015, p.67) asserts that Czechoslovakia 38-89: Assassination "excels in depicting small personal compromises leading to greater human tragedies, yet doesn't judge the protagonists - this is something left to the players."

While the game's historical content was widely commended, the game mechanics attracted criticism. Grygar (2015, p.67), for example, notes that Czechoslovakia 38-89: Assassination constitutes "a suggestive excursion to a dark period of our history that functions well as an interactive document. We can only imagine how it could have worked if the authors had included more well-designed game elements". By the same token, the game is described by Kouba (2015) as "a unique experiment that defines a new genre of interactive educational documents", but maintains that if evaluated as a game, "it would fail".

Online forums and news groups discussing the game prior to commercial release gave it a critical reception that often directed attention to possible impacts of alleged ideological content. Jiřička's (2013) study of the game, for instance, triggered a series of negative 
H. Pötzsch and V. Šisler: 'Playing Cultural Memory', Games \& Culture, 2016 (online first)

responses in the commentary section under his article where contributors warned against what was perceived as ideological content conveyed by the title. Statements such as "if they [the developers of the game] want to teach kids history, they should use facts and not propaganda", or "during the totalitarian [Communist] regime kids had to study poems about Lenin, now they are given the 'right' version of history through a video game" give an impression of this particular segment of the debate.

In addition, several contributors to the same commentary section objected to the inclusion of Roma and Sudeten-German memories into a "Czech national discourse" demanding that "[the designers] should rather make a game on teaching Gypsies how to work and how to acquire the social norms of the society they live in", or who argued that "after the atrocities of the war [...] people made the genuine struggle to expel the traitors from 'Sudetenland' and to build a truly national - our -Czechoslovak Republic'. Also the negative comments cited above, however, apparently treat the game as a relevant historical articulation and challenge it precisely due to what is perceived as misdirected memory-making potentials.

In sum, the pluri-medial level reveals a widespread perception of Czechoslovakia 3889: Assassination as a relevant articulation within Czech historical discourse and beyond. Both critics and promoters apparently agree to the discursive significance of the game, a fact that points to a certain realization of the potentials for memory-making in pluri-medial constellations.

\section{Games, Memory, History: A Conclusion}

The present contribution argued for the relevance of computer games for historical discourse and memory politics. Through a formal analysis of two game titles, Call of Duty: Black Ops and Czechoslovakia 38-89: Assassination, we firstly sketched out a generic rhetoric of war characteristic of mainstream first-person shooters, before we showed how a serious historical 
H. Pötzsch and V. Šisler: 'Playing Cultural Memory', Games \& Culture, 2016 (online first)

game for education enables a productive questioning of established historical discourses and frames. In doing so, we combined theories and concepts from the fields of game studies and cultural memory research to develop methodological tools for an analysis of games as media for historical understanding and practice.

We found that the game mechanics of Call of Duty: Black Ops narrowly limit the possibilities for free exploration of historical settings and events, and reduce players' creative involvement to mainly battle-related tactical considerations. The game invites a disambiguation of simulated battlefield as well as historical discourse and, as such, reiterates received monolithic cultural frames of war. Cold war history and its various military hot spots are transformed into convenient settings of a conventional game narrative based on clear oppositions and simplifying normative identities.

In contrast, Czechoslovakia 38-89: Assassination deliberately includes the accounts of a variety of characters with widely different socio-cultural backgrounds and political preferences. By these means, the game makes accessible a kaleidoscopic image of history as composed of multifaceted, intimate, and idiosyncratic personal recollections rather than a linear trajectory of events presented as the result of unambiguous chains of cause and effect. By these means the game productively realizes the potentials of the game form to enable playful explorations of contingencies and contradictions regarding the constant collective negotiation of a shared past and denies players the false safety of allegedly authoritative historical facts.

While Czechoslovakia 38-89: Assassination invites players to actively explore a past composed of different and disparate recollections and deliberately encourages meta-historical reflection, Call of Duty: Black Ops reduces past events to mere background props. Both games, however, function as conveyors of history. Particular formal devices charge the various representations emerging in and through game play with certain memory making 
H. Pötzsch and V. Šisler: 'Playing Cultural Memory', Games \& Culture, 2016 (online first)

potentials that spread through, and actualize in, pluri-medial networks. Consequently, both games need to be taken seriously and merit the critical attention of historians and scholars of cultural memory.

\section{References}

Assmann, J. (1992). Das kulturelle Gedächtnis. München: Beck.

Assmann, J. (2008). Communicative and Cultural Memory. In A. Erll \& A. Nünning (Eds.), Cultural Memory Studies: An Interdisciplinary Handbook (pp.109-118), Berlin: Walter de Gruyter.

Associated Press. (2010a). Call of Duty Breaks Sales Record. CBC News, November 11, 2010, http://www.cbc.ca/news/technology/call-of-duty-breaks-sales-record-1.949952 Associated Press. (2010b). Cuba Denounces 'Virtual' Castro Plot in New Game. November 10,

http://wayback.archive.org/web/20101113200931/http://finance.yahoo.com/news/Cubadenounces-virtual-Castro-apf-2373678391.html? $\mathrm{x}=0$ \&.v $=4$

Bavelier, D. (2012). Your Brain on Video Games. TEDxCHUV (filmed June 2012), http://www.ted.com/talks/daphne bavelier your brain on video games\#t-10041

Bogost, I. (2007). Persuasive Games: The Expressive Power of Video Games. Cambridge: MIT Press.

Bohning, D. (2005). The Castro Obsession: US Covert Operations Against Cuba 1959-1965. Dulles: Potomac Books.

Bond, P. (2011). “Call of Duty: Black Ops” Is Best-Selling Video Game Ever in US. The Hollywood Reporter, October 3, http://www.hollywoodreporter.com/news/call-dutyblack-ops-is-166625

Butler, J. (2009). Frames of War: When is Life Grievable? London: Verso. 
H. Pötzsch and V. Šisler: 'Playing Cultural Memory', Games \& Culture, 2016 (online first)

Chapman, A. (2012). Privileging Form over Content: Analysing Historical Videogames. Journal of Digital Humanities, 1(2).

Chapman, A. (2013). Is Sid Meier's Civilization History? Rethinking History: The Journal of Theory and Practice, 17, 312-332.

Erll, A. \& Rigney, A. Eds. (2009). Mediation, Remediation, and the Dynamics of Cultural Memory. Berlin: Walter De Gruyter.

Erll, A. (2011). Memory Culture. Basingstoke: Palgrave Macmillan.

Erll, A. (2008). Literature, Film, and the Mediality of Cultural Memory. In A. Erll \& A. Nünning (Eds.), Cultural Memory Studies: An Interdisciplinary Handbook (pp.389-398), Berlin: Walter de Gruyter.

Galloway, A.R. (2006). Gaming. Essays on Algorithmic Culture. Minneapolis: University of Minnesota Press.

Grygar, L. (2015). Československo 38-89: Atentát. Škola hrou. Level, 257, 66-67.

Hartmann, T. \& Vorderer, P. (2010). It's Okay to Shoot a Character: Moral Disengagement in Violent Video Games. Journal of Communication, 60(1), 94-119.

Jiřička, J. (2013). Historie není nuda, ukáže školákům hra. Provede je nacismem i totalitou. iDnes, September 14, http://zpravy.idnes.cz/pocitacova-hra-k-vyuce-dejepisu-d3s/domaci.aspx?c=A130909_162437_domaci_jj

Kouba, J. (2015). Československo 38-89: Atentát - vzdělávání na prvním místě. Bonusweb, June $\quad 28, \quad$ http://bonusweb.idnes.cz/ceskoslovensko-38-89-atentat-recenze-duq/Recenze.aspx?c=A150624 190603 bw-pc-recenze oz

Landsberg, A. (2005). Prosthetic Memories. New York: Columbia UP.

McCall, J. (2012). Historical Simulations as Problem Spaces: Criticism and Classroom Use. Journal of Digital Humanities, 1(2).

Mouffe, C. (2009). The Democratic Paradox. London: Verso. 
H. Pötzsch and V. Šisler: 'Playing Cultural Memory', Games \& Culture, 2016 (online first)

Nora, P. (1984). Les Lieux de Mémoire. Paris: Gallimard.

Peterson, R.D., Miller, A.J. \& Fedorko, S.J. (2013). The Same River Twice: Exploring Historical Representation and the Value of Simulation in the "Total War", "Civilization", and "Patrician" Franchises. In A.B.R. Elliott \& M.W. Kapell (Eds.), Playing with the Past: Digital Games and the Simulation of History (pp.33-48), New York: Bloomsbury.

Pötzsch, H. (2013). Ubiquitous Absence: Character Engagement in the Contemporary War Film. Nordicom Review, 34, 125-144.

Pötzsch, H. (2015). Selective Realism: Filtering Experiences of War in the First- and ThirdPerson Shooter. Games \& Culture, pre-publication, doi: 10.1177/1555412015587802.

Ramsay, D. (2015). Brutal Games: Call of Duty and the Cultural Narrative of World War II. Cinema Journal, 54, 94-113.

Reisner, C. (2013). “The Reality Behind It All Is Very True”: Call of Duty: Black Ops and the Remembrance of the Cold War. In A.B.R. Elliott \& M.W. Kapell (Eds.), Playing with the Past: Digital Games and the Simulation of History (pp.247-260), New York: Bloomsbury. Rosenstone, R.A. (2001). The Historical Film: Looking at the Past in a Postliteral Age. In M. Landy (Ed.), The Historical Film: History and Memory in Media (pp.50-66), New Brunswick: Rutgers University Press.

Rosenstone, R.A. (2006). History on Film/Film on History. Harlow: Pearson Education Limited.

Salvati, A.J. \& Bullinger, J.M. (2013). Selective Authenticity and the Playable Past. In A.B.R. Elliott \& M.W. Kapell (Eds.), Playing with the Past: Digital Games and the Simulation of History (pp.153-167), New York: Bloomsbury.

Schulzke, M. (2013). Refighting the Cold War: Video Games and Speculative History. In A.B.R. Elliott \& M.W. Kapell (Eds.), Playing with the Past: Digital Games and the Simulation of History (pp.261-277), New York: Bloomsbury. 
H. Pötzsch and V. Šisler: 'Playing Cultural Memory', Games \& Culture, 2016 (online first)

Schut, K. (2007). Strategic Simulations and Our Past: The Bias of Computer Games in the Presentation of History. Games \& Culture, 2, 213-235.

Šisler, V., Selmbacherová, T., Pinkas, J., \& Brom, C. (2014). Teaching Contemporary History to High School Students: The Augmented Learning Environment of Czechoslovakia 3889. Masaryk University Journal of Law and Technology, 8(1), 99-122.

Uricchio, W. (2011). Simulation, History, Computer Games. In J. Raessens \& J. Goldstein (Eds.), Handbook of Computer Game Studies (pp.327-338), Cambridge: MIT Press.

White, H. (1980). The Value of Narrativity in the Representation of Reality. Critical Inquiry, $7,5-27$

${ }^{\mathrm{i}}$ Operation 40 was a secret CIA-programme approved by President Eisenhower in 1960 and presided over by then Vice-president Richard Nixon. The programme had the violent toppling of left-leaning governments in Latin America as its main objective - including the assassination of Fidel Castro - and was charged with the take-over of Cuba after the Bay of Pigs invasion in 1961 (see for instance Bohning, 2005).

ii This title was taken over by Grand Theft Auto V (Rockstar Games, 2013) in November 2014.

${ }^{i i i}$ A majority of these 600 million hours have been played in multiplayer sessions. As such, the number does not evidence an exposure of players to the historical content of the campaign mode. However, it provides a clear indication to the general cultural currency of the game.

iv See Wikipedia for further details:

https://en.wikipedia.org/wiki/Call of Duty: Black_Ops\#Reception

"All translations from Czech originals by Vit Šisler. 